Nippon Suisan Gakkaishi $\quad \mathbf{5 8 ( 5 ) , 9 0 9 - 9 1 3 ( 1 9 9 2 )}$

\title{
凍結貯蔵力キむき身の加熱時に起こる褐変
}

\author{
中村芓，前由浩幸，樋口雅義，濱洋一郎
}

(1991 年 11 月 5 日受付)

\section{Browning Occurring by Heating of Shelled Oyster Stored at Frozen Temperature}

Takashi Nakamura,* Hiroyuki Maeda,* Masayoshi Higuchi,* and Yoichiro Hama*

\begin{abstract}
Causes of undersirable browning which occur as a result of heating of shelled oysters stored at $-35^{\circ} \mathrm{C}$ and characteristics of brown pigments produced were investigated. Peroxide values (100-500 meq $/ \mathrm{kg}$ lipids), which were measured by HPLC, of lipids in potential browning portions were more than ten times larger than those in normal portions, and nearly half of the polyunsaturated fatty acids of the former lipids had been oxidized during storage at $-35^{\circ} \mathrm{C}$ for 6 to 16 months. Discoloration by steaming resulted in a decrease in peroxide value and polymerization of oxidized glycerides. Brown polymers obtained after steaming for 20 min were lipophilic but not hydrophilic. They were fluorescent substances composed of 2-5 molar oxidized glycerides, mainly triglycerides, having intact saturated fatty acids and oxidized polyunsaturated fatty acids, and of nitrogeneous compounds $(1.0-1.5 \% \mathrm{~N})$.
\end{abstract}

凍結眝蔵に伴ら魚や魚肉の悪変に関わる諸問題につい ては，数十年来数多くの研究がなされてきた。しかしカ キについての報告は少ない。羽田野ら”はマガキ凍結詝 葴中の不快味の発生上変色について研究し，不快味の原 因が脂溶性画分にあり，眝蔵中に増加する遊離脂肪酸や 低級アルデヒド等が関与する事を示唆した。交た、承溶 性変色物質の生成についても言及した。Jeong ら²凍 結貯蔵中の脂省化とその防止法について研究し，脱酸 素刘の有效性を明らかにしている。盖殖力キは冬季にむ き身にされ，一部は凍結され輸出，加工に供せられる。 カキむき身を東結眝蔵したものを，惹熟あるいは蒸㶨す ると軟体部が褐変するものがある。貯蔵期間が短いもの は裀変部も小さく色も薄いが，睁蔵期間が長くなるにつ れて、褐変部は広がり濃い赤褐色を呈し商品価值を落上 to

本研究に执いては， $-35^{\circ} \mathrm{C}$ に貯蔵されだカキを用い， 加熱に上り軟体部表層に局部的に出現する螕変部と周縁 の正常部との違いから変色の原因を探り，さららに生成し た褐変物質の性状を榆討し，変色防止の指針を得る事を 目的とした。

$$
\text { 实 験 方 法 }
$$

試料堆殖マガキCrassostrea gigas（広島県，1990年
産）のグレーズしたをき身を一35ㄷ 蔵したるのを用いた。

加熱变色 むき身をそのま蒸者しだ。また，むき身 を倲結乾熳後所定の部分をかみそりでかき取って得た物 状物については，同重量の脱イオン水を添加後蒸煮した。 脂睤の抽出 かみそりでかき取った凍結较燥粉状物あ るいはそれらの加熱物 $(0.2 \sim 1.0 \mathrm{~g})$ を $50 \mathrm{ml}$ 容の遠心管 に科り取り，30 $\mathrm{m} l$ の $\mathrm{CHCl}_{3}: \mathrm{CH}_{3} \mathrm{OH}(2 / 1, \mathrm{v} / \mathrm{v})$ を加 之, 水冷しながらウルトラディスパーザー(ヤマト科学, LK-21 型)で 3 分間抽出した。遠心分離後万別して得た 抽出液に $7.5 \mathrm{ml}$ の脱イオン水を加党かくはん後, 遠心 分離により二層に分け，下㬝部上り脂質を得た。

過酸化脂啠の定量 過酸化脂質による triphenylphosphine の酸化によって定量的に生成する triphenylphosphine oxide を高速液体クロマト法 (Nova-pak Silica カラム, 3.9 i.d. $\times 150 \mathrm{~mm}$, Waters Assoc. Inc.; 溶出液. $n$-hexane/2-propanol 混合液; 流速, $1.5 \mathrm{ml} / \mathrm{min}$ ) で分析 した。

脂肪酸の分析 $5 \% \mathrm{HCl} / \mathrm{CH}_{3} \mathrm{OH}$ でェステル交換4後, ガスクロマト法 (Ulbon HR-SS-10 カラム, $0.25 \mathrm{~mm} \times$ $25 \mathrm{~m}$, 信和化工； $150 \rightarrow 220^{\circ} \mathrm{C}, 4^{\circ} \mathrm{C} / \mathrm{min}$ 界温) で分析し た。また，脂肪酸量の算出に内部標準物質として methyl tridecanoate (Serdary Research Lab.)を用いた。

*九州大学農学部水産化学第二教室 (Laboratory of Fisheries Technology, Faculty of Agriculture, Kyushu University, Hakozaki, Higashi, Fukuoka 812, Japan). 
变色脂啠の分画上分析 抽出脂質液体》口マト法 [Toyopearl HW-40 (東ソー) カラム, $1 \times 30 \mathrm{~cm} \times 2$ 本; 溶出渐, $\mathrm{CHCl}_{3}: \mathrm{CH}_{3} \mathrm{OH}(2 / 1, \mathrm{v} / \mathrm{v})$; 流速, $\left.1 \mathrm{ml} / \mathrm{min}\right]$ で分画後，分子量の最も大きい重合物画分を分取した。 溶出脂質の確認は薄圈クロマト法 I(Silicagel 60, Merck; 屡開剤, diethyl ether $/ n$-hexane/acetic acid (50/50/1, $\left.\mathrm{v} / \mathrm{v} / \mathrm{v}), \mathrm{CHCl}_{s} / \mathrm{CH}_{3} \mathrm{OH} / \mathrm{H}_{2} \mathrm{O}(65 / 25 / 4, \mathrm{v} / \mathrm{v} / \mathrm{v})\right]$ と各種の 檟䨏呈色剂 ${ }^{5}$ に上った。分子量既知の標準ポリスチレン (GL サイェンス) 括よび trilinolein, cholesteryl palmitate, cholesterol, methyl linoleate (東京化成工業) を上 述の液体クロマト法で分析し, 褐変重合物の分子量を推 定した。リンの定量は Harris 等の方法(b)にった。炭 素, 我素, 窒素量の分析は元素分析に上った。赤外線吸 収スペクトルを $\mathrm{CHCl}_{9}$ 溶液で測定した。

\section{結果}

変色部脂賴の分析 蒸薏に上り褐変した組織部分のみ をピンセットで集めてかくはん抽出し，(1) 有機溶媒可 溶部，（2）水可溶部，（3）不溶部（残さ）に分け变色度

Table 1. Lipid peroxide contents of potential browning portions (yellowish portions) and normal portions of ice-glazed oysters stored at $-35^{\circ} \mathrm{C}$

\begin{tabular}{cccc}
\hline Sample & $\begin{array}{c}\text { Lipid } \\
\text { content*1 } \\
\text { (\% dry wt.) }\end{array}$ & $\begin{array}{l}\text { PV*2 of } \\
\text { normal } \\
\text { portion } \\
\text { (meq/kg } \\
\text { lipid) }\end{array}$ & $\begin{array}{l}\text { PV*2 of } \\
\text { yellowish } \\
\text { portion } \\
\text { (meq/kg } \\
\text { lipid) }\end{array}$ \\
\hline 1 & 13.2 & 6.7 & 380 \\
2 & 14.2 & 9.2 & 100 \\
3 & 15.5 & 13.4 & 476 \\
4 & 15.0 & 13.7 & 172 \\
5 & 13.2 & 26.8 & 305 \\
\hline
\end{tabular}

*1 Lipid content of normal portions.

*2 Peroxide value.

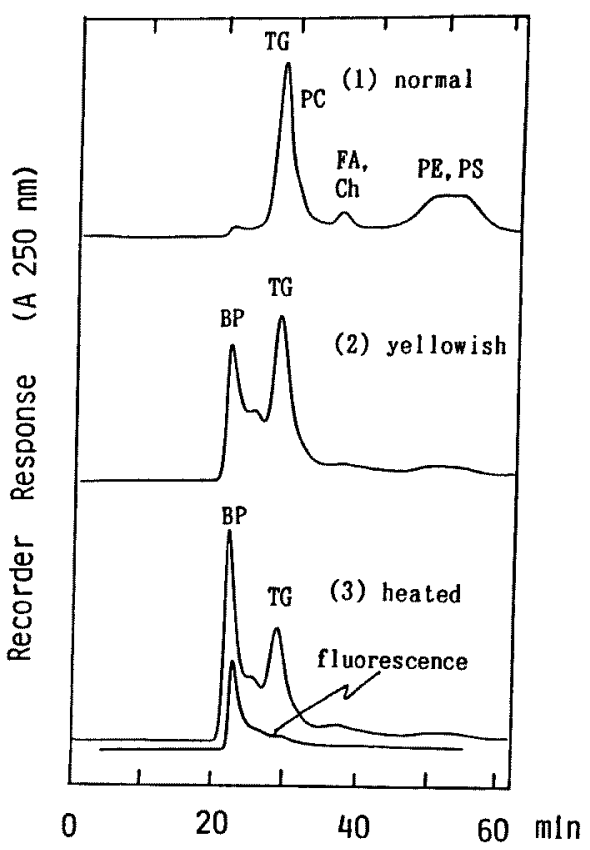

Fig. 1. Gel chromatography of oyster lipid preparations. Lipids from (1) normal portion (PV 26.8), (2) potential browning portion (PV 305), and (3) brown portion (PV 23.5) obtained after steaming of (2) were separated on a column of Toyopearl HW-40 $(1 \times 30 \mathrm{~cm}$ $\times 2$, Toso, Tokyo, Japan) with $\mathrm{CHCl}_{3} / \mathrm{CH}_{3} \mathrm{OH}$ $(2 / 1, \mathrm{v} / \mathrm{v})$ at a flow rate of $1 \mathrm{~m} / \mathrm{min}$, and monitored by UV absorption at $250 \mathrm{~nm}$. Brown polymers eluted were also detected fluorometrically (excitation $363 \mathrm{~nm}$, emission 407 $\mathrm{nm})$.

$\mathrm{BP}$, brown polymers; $\mathrm{TG}$, triglycerides; PC, phosphatidylcholine; FA, fatty acids; $\mathrm{Ch}$, cholesterol; PE, phosphatidylethanolamine; PS, phosphatidylserine.

Table 2. Changes in peroxide value and discoloration rate of oyster lipid preparations by steaming

\begin{tabular}{|c|c|c|c|c|}
\hline \multirow[b]{2}{*}{$\begin{array}{l}\text { Sampling } \\
\text { portion }\end{array}$} & \multicolumn{2}{|c|}{ PV } & \multicolumn{2}{|c|}{ Discoloration } \\
\hline & $\begin{array}{l}\text { Before } \\
\text { heating }\end{array}$ & $\begin{array}{l}\text { After } \\
\text { heating } \\
\text { ipid }\end{array}$ & $\begin{array}{l}\text { Before } \\
\text { heating } \\
\mathbf{A}_{430 \mathrm{~nm}}\end{array}$ & $\begin{array}{l}\text { After } \\
\text { heating }\end{array}$ \\
\hline \multicolumn{5}{|c|}{ Yellowish portion } \\
\hline $1^{* 1}$ & 476 & 295 & 0.292 & 0.491 \\
\hline $2 * 2$ & 380 & 26.3 & 0.256 & 0.824 \\
\hline $3^{* 8}$ & 305 & 23.5 & 0.698 & 1.647 \\
\hline \multicolumn{5}{|c|}{ Normal portion } \\
\hline $1^{* 1}$ & 13.3 & 12.9 & 0.050 & 0.106 \\
\hline $2 * 2$ & 6.7 & 6.7 & 0.062 & 0.075 \\
\hline $3^{* 8}$ & 26.8 & 16.0 & 0.088 & 0.120 \\
\hline
\end{tabular}

*1-a Samples in test bubes were heated for 3,10 , and 20 min respectively in boiling water.

*4 Absorbance at $430 \mathrm{~nm}$ in $\mathrm{CHCl}_{3} / \mathrm{CH}_{8} \mathrm{OH}(2 / 1, v / v)$. 
を比較すると，(1) は濃い褊色，(2) はごく淡い黄色， （3）は褐色を呈した。また，峦色は組織のごく表層部の み隹察された。これらの事実は加熱による褐变が主に 油焼けによることを推測させた。凍結眝蔵力キを取出し， 黄变を起こしている物を選別し涷結乾燥した。乾燥物表 面に偏在する黄色部（加熱により裮変する部分）と周緣 の正常部を別々に，複数個のカキからかみそりを用いて が取り、脂質を抽出した。䁕質含量は13-16\% 乾重量

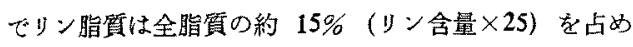

た。Table 1 に示しているように，黄色部と正常部の美 異は明白で黄色部脂質はいずれも過酸化を起こしてい た。凍結乾燥後に得た黄色部之正常部の粉状物を加水蒸 薏後抽出した脂筫区分について，過酸化物価 (PV) と変 色度 $\left(\mathrm{A}_{480}\right)$ を測定した (Table 2)。加熱によるPV の減 少と変色の高進が东られた。すなわら，加熱による正常 部脂質の变色虫小さく，過酸化が進行している黄色部脂 質が変色比大き奇与していた。構成脂眆酸の定量分析 を行いTable 3 の結果を得た。黄色部と正常部との違い

Table 3. Fatty acid contents of oyster lipid preparations

(\% in lipids)

\begin{tabular}{|c|c|c|c|c|c|c|}
\hline \multirow[b]{2}{*}{ Fatty acid } & \multicolumn{2}{|c|}{ Normal portion } & \multicolumn{2}{|c|}{ Yellowish portion } & \multicolumn{2}{|c|}{ Brown polymer } \\
\hline & $\begin{array}{c}\text { Before } \\
\text { heating } \\
\text { (PV 26.8) }\end{array}$ & $\begin{array}{c}\text { After } \\
\text { heating } \\
\text { (PV 16.0) }\end{array}$ & $\begin{array}{r}\text { Before } \\
\text { heating } \\
(\text { PV 305) }\end{array}$ & $\begin{array}{c}\text { After } \\
\text { heating } \\
\text { (PV 23.5) }\end{array}$ & $\cos ^{(1)}$ & $(2)^{* 2}$ \\
\hline $14: 0$ & 2.9 & 3.1 & 3.0 & 3.1 & 2.5 & 1.7 \\
\hline $15: 0$ & 0.4 & 0.4 & 0.5 & 0.5 & 0.4 & 0.2 \\
\hline $16: 0$ & 15.5 & 15.2 & 14.7 & 15.1 & 13.1 & 9.2 \\
\hline $17: 0$ & 2.5 & 2.4 & 2.2 & 2.2 & 2.1 & 1.4 \\
\hline $18: 0$ & 2.8 & 2.8 & 2.7 & 2.7 & 2.3 & 1.7 \\
\hline$\sum$ Satd. & 24.1 & 23.9 & 23.1 & 23.6 & 20.4 & 14.2 \\
\hline $15: 1(n-8)$ & 0.3 & 0.3 & 0.3 & 0.2 & 0.2 & 0.2 \\
\hline $16: 1(n-7)$ & 2.5 & 2.6 & 2.3 & 2.4 & 1.7 & 1.2 \\
\hline $18: 1(n-11)$ & 1.1 & 1.1 & 1.0 & 1.0 & 0.8 & 0.6 \\
\hline $18: 1(n-9)$ & 2.5 & 2.6 & 2.1 & 2.2 & 1.6 & 1.1 \\
\hline $18: 1(\mathrm{n}-7)$ & 5.5 & 4.9 & 4.5 & 4.5 & 3.3 & 2.5 \\
\hline $20: 1(n-9)$ & 1.1 & 1.1 & 1.0 & 1.1 & 0.5 & 0.4 \\
\hline $20: 1(n-7)$ & 2.0 & 2.0 & 1.9 & 1.9 & 1.4 & 1.1 \\
\hline$\sum$ Monoene & 15.0 & 14.6 & 14.1 & 13.3 & 9.5 & 7.1 \\
\hline $16: 2(n-6)$ & 1.1 & 1.1 & 1.2 & 1.2 & 1.0 & 0.7 \\
\hline $16: 2(n-4)$ & 0.4 & 0.4 & 0.3 & 0.4 & nil & nil \\
\hline $18: 2(n-6)$ & 1.1 & 1.2 & 0.7 & 0.7 & 0.3 & 0.2 \\
\hline $18: 2(n-4)$ & 0.6 & 0.6 & 0.4 & 0.4 & 0.1 & 0.1 \\
\hline $20: 2 \mathrm{NMI}^{* 1}$ & 1.0 & 1.0 & 0.9 & 0.9 & 0.5 & 0.4 \\
\hline $22: 2 \mathrm{NMI}^{* 1}$ & 1.5 & 1.9 & 1.5 & 1.8 & 0.7 & 0.5 \\
\hline$\sum$ Diene & 6.7 & 6.2 & 5.0 & 5.4 & 2.7 & 1.9 \\
\hline $18: 3(n-3)$ & 1.4 & 1.4 & 0.8 & 0.8 & 0.1 & 0.1 \\
\hline $22: 3(n-6)$ & 1.1 & 1.1 & 0.5 & 0.5 & 0.1 & 0.1 \\
\hline$\sum$ Triene & 2.5 & 2.5 & 1.3 & 1.3 & 0.2 & 0.2 \\
\hline $18: 4(n-3)$ & 4.4 & 4.3 & 2.4 & 2.4 & 0.4 & 0.3 \\
\hline $20: 4(n-6)$ & 1.1 & 1.1 & 0.7 & 0.6 & 0.1 & 0.1 \\
\hline $20: 4(n-3)$ & 0.5 & 0.6 & 0.3 & 0.3 & 0.1 & 0.1 \\
\hline$\Sigma$ Tetraene & 6.0 & 6.0 & 3.4 & 3.3 & 0.6 & 0.5 \\
\hline $20: 5(n-3)$ & 19.3 & 18.7 & 9.3 & 9.1 & 1.4 & 1.1 \\
\hline $21: 5(\mathrm{n}-3)$ & 0.4 & 0.4 & 0.2 & 0.3 & 0.1 & 0.1 \\
\hline $22: 5(n-3)$ & 0.7 & 0.8 & 0.4 & 0.4 & 0.1 & 0.1 \\
\hline$\sum$ Pentaene & 20.4 & 19.9 & 9.9 & 9.8 & 1.6 & 1.3 \\
\hline $22: 6(n-3)$ & 12.1 & 12.0 & 5.2 & 5.1 & 0.9 & 0.7 \\
\hline Total & 85.3 & 85.1 & 61.0 & 61.8 & 35.6 & 25.6 \\
\hline
\end{tabular}

The fatty acid contents ( $\%$ in lipids) were calculated by using an internal standard, methyl tridecanoate.

*1 Non-methylene interrupted type.

*2 Highly polymerized specimen left in air for several days after preparation. 
Table 4. Ultimate analysis of brown polymers

\begin{tabular}{|c|c|c|c|c|c|c|c|c|c|}
\hline \multirow{2}{*}{$\begin{array}{l}\text { Brown } \\
\text { polymer }\end{array}$} & \multirow{2}{*}{$\frac{\mathrm{PV}^{* 1}}{(\mathrm{meq} / \mathrm{kg})}$} & \multirow{2}{*}{$\frac{\mathrm{A}_{480} * 2}{(10 \mathrm{mg} / \mathrm{ml})}$} & \multicolumn{4}{|c|}{ Element composition } & \multirow{2}{*}{$\begin{array}{c}M W \\
(N=1)\end{array}$} & \multirow{2}{*}{$\begin{array}{l}\text { Ash } \\
(\%)\end{array}$} & \multirow{2}{*}{$\underset{(\%)}{P}$} \\
\hline & & & $\mathbf{H}$ & $\mathrm{C}$ & $\mathbf{N}$ & 0 & & & \\
\hline 1 & 37.4 & 3.29 & 114 & 72 & 1 & 15 & 1232 & 1.87 & 0.55 \\
\hline 2 & 34.5 & 5.07 & 84 & 52 & 1 & 12 & 914 & 2.18 & 0.40 \\
\hline 3 & 16.7 & 3.10 & 89 & 57 & 1 & 12 & 979 & 2. 22 & 0.49 \\
\hline
\end{tabular}

*1 Peroxide value (meq/kg lipid)

*2 Absorbance at $430 \mathrm{~nm}$ in $\mathrm{CHCl}_{3} / \mathrm{CH}_{3} \mathrm{OH}(2 / 1, \mathrm{v} / \mathrm{v})$.

はトリエン以上の高度不飽和脂肪酝量に沶いて明白で， PV 305 程度の酸化度で約 $50 \%$ の高度不飽和酸が変質し たことを示している。また，加熱操作は脂肪酸量にほと んど影響を与えていなかった。以上の結果は，加熱褐变 をおこす局部では構成脂質の高度不飽和脂肪酸が酸化さ れ一部はすでに黄変し，加熱により一举に褐色物質を生 成するものと推測させる。この事をさらに検討するため に Toyopearl HW-40カラムを用いるゲルタロマト法で 分析した。Fig. 1-(1) の正常部脂質 (PV 26.8) の例に示 すよらに，吸着による溶出の遅れが見られたニンヒドリ ン陽性のリン䁕質 (PE, PS, 50-52 分) を除き，28.6 分 のトリク゚リセリド (TG) 以下分子量の大きい順に溶出し た。Fig. 1-(2) の黄色部脂質 (PV 305) と和いては，50-52 分のリン脂質ピーク (PE, PS) むほとんど消失し 21.6, 24.9 分に新たにピークが観察された。黄色部を蒸煮後に 得た脂筫部 (PV 23.5) のクロマトグラム (Fig. 1-(3)) で は28.6分の過酸化トリグリ七りド，過酸化りン脂質を 含さピークが減少し，21.6 分の褐色物筫ピーク (BP) が 著しく增大した。これらの結果は加熱に伴う過酸化物の 分解之褐色重合物の生成の事実を裹付けた。

褐色物面の性变色度を異にする陚料からゲルクロ マト法で分取した褐色重合物は，いずれも蓝光 (Ex 363 $\mathrm{nm}, \mathrm{Em} 407 \mathrm{~nm})$ を有し, ポリスチレン標準分子量標品 の溶出位膡から推定される分子量は約 5,000, 脂質標品 trilinolein, cholesteryl palmitate 等で推定される分子量 は2,000 程度であった。赤外スべクトル分析の結果は土 ステル結合による吸取 $\left(\nu \mathrm{C}=\mathrm{O}, 1730 \mathrm{~cm}^{-1} ; \nu \mathrm{C}-\mathrm{O}-\mathrm{C}\right.$, $1160 \mathrm{~cm}^{-1}$ ) の他 $3300 \mathrm{~cm}^{-1}$ 域にขOH, $1600-1700 \mathrm{~cm}^{-1}$ 域にンNH の吸収を示した。褐色物質を構成与る未酸化 の脂肪酸総量は正常部位 (85\%) の 1/2 1/3 で飽和酸， モノエン酸が主成分で高度不飽和脂肪酸量はかずかであ った (Table 3)。场，これらの元素分析等の結果を Table 4 に示した。すなわち, 褐色物質は2 5モルト程度 のトリグリセリドやリン脂質の重合物で，構成脂肪酸の らら䭂和脂肪酸ははとんぞ元のままであるが，不飽和脂 肪酸が酸化され，1 脂肪酸当たり新たに 1 2 モル程度 の酸素が付加し，1トリグリセリド当り 1 モル程度の望 素化合物之結合し (Table 3,4), 着色之蛍光性の官能基
を形成していると推测される。むた，褐色重合物に占め るリン脂䝷の割合は $10 \%$ 程度（リン含量 $\times 25$ ) と推測 される。

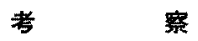

凍結貯蔵力キの㐗熟時に起こる褐変は，前述の結果か ら脂質の酸化によることが明白になった。酸化脂質は加 熱により窒妻化合物と反応しながら重合し，褐色物筫を

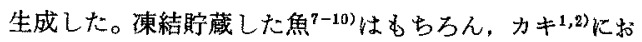
いてる，ホスホリパーゼAやリパーセ等の作用に上り遊 離脂肪酸が䈏積することは良く知られている。この時生 成した脂肪酸がその後の脂質酸化に促進的であるか，む るいは抑制的であるかについては議論が別れる11,12)が， 本実験で得た褐色物質は，醉素的に生成した遊離脂肪酸 の酸化と相互の重合によって生成したのではなく，大部 分はグリセリドの形で重合したと考えられる。褐変は内 藏を包む軟体部，外套膜，鰓等いずれの組織に扣いても ごく表層にのみ出現することから，脂質酸化の原因は内 因性ではなく不完全なグレーズ被覆等による外気酸素と の接触に园ると推測される。生成した褐色物質は親油性 であり，親水性色素の生成はわずかでょイラード反応 (精ーアミノ反応) の奇与は小さい之考学られる。また， ゲルクロマト法で調製した褐色物質は空気中に放着する とさらに重合が進行し，最終的には溶媒に不溶性の樹脂 状物質になった。本研究に用いた脂質過酸化物測定法は 今回新しく開発したもので，mg 以下の脂質を用いてピ コモルレベルの過酸化物の定量が可能で，本実験の様に 試料量に制約がある場合は特に有效であった。

$$
\text { 腉 辞 }
$$

本研究俚文部省平成 2 年度科学研究費（試験研究）比 よったもので，試験研究全体の企画，取りまとめに尽力 された東京水産大学小泉千秋教授に深く感謝する。

文献

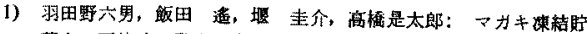

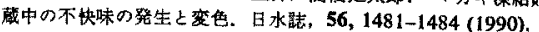

2) B.-Y. Jeong, T. Ohshima, C. Koizumi, and Y, Kanou: Lipid deterioration and its inhibition of Japanese oyster 
Crassostrea gigas during frozen storage. Nippon Suisan Gakkaishi, 56, 2081-2091 (1990).

3) T. Nakamura and H. Maeda: A simple assay for lipid hydroperoxides based on triphenylphosphine oxidiation and high-performance liquid chromatography. Lipids, 26, 765-768 (1991).

4) W. W. Christie: Lipid Analysis. Pergmann Press Ltd., Oxford, 1973, pp. 88-89.

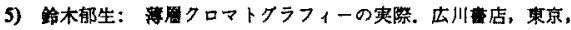
1963, pp. 176-185.

6) W. D. Harris and P. Popat: Determination of the phosphorous content of lipids. J. Am. Oil Chem. Soc., 31, 124-127 (1954)

7) W. J. Dyer and D. I. Fraser: Protein in fish muscle. 13 Lipid hydrolysis. J. Fish. Res. Bd. Canada, 16, 43-52 (1959).

8) J. Olley, R. Pirie, and H. Watoson: Lipase and phospholipase activity in fish skeletal muscle and its relation- ship to protein denaturation. J. Sci. Food Agric, 13, $501-516$ (1962).

9) I. Bosund and B, Ganrot: Lipid hydrolysis in frozen Baltic herring. J. Food Sct., 34, 13-18 (1969).

10) M. Toyomizu, K. Hanaoka, K. Satake, and H. Nakagawa Effect of storage temperature on accumulation of glycerylphophorylcholine and decomposition of phosphatidyl choline in fish muscle during cold storage. Nippon Suisan Gakkaishi, 43, 1181-1187 (1977).

11) F. Mazeaud and E. Bilinski: Free fatty acids and onset of rancidity in rainbow trout (Sarmo gairdneri) flesh. Effect of phospholipase A: J. Fish. Res. Bd. Canada, 33, 1297-1302 (1976).

12) R. L. Shewfelt, R. E. MacDonald, and H. O. Hultin: Effect of phospholipid hydrolysis on lipid oxidation in flounder muscle microsomes. J. Food Sci. 46, 1297-1301 (1981). 